\title{
Soil temperature and horticultural traits as influenced by mulching materials and orchard floor management practices in ber (Zizypus mauritiana Lamk.)
}

\author{
J.S. BRAR, K.S. GILL, KIRANDEEP KAUR and GAGANDEEP KAUR \\ Department of Fruit Science, Punjab Agricultural University, Ludhiana-141001 \\ Corresponding author: jsbrar74@pau.edu
}

\begin{abstract}
Different type of mulches viz. paddy straw mulch (PSM), black polythene mulch (BPM), and white polythene mulch (WPM) were spreaded under the canopies of Indian ber (Zizypus mauritiana Lamk.) trees in second fortnight of October. The treatments of inter-cultivation (IC) and chemical weed management (CWM), and control trees were also kept for comparative analysis. The daily soil temperature recorded at 0900, 1200, 1400 and 1700 hours from October to April months during 2018-19 and 2019-20 revealed significant variations under different treatments. The respective soil temperature variation during $1^{\text {st }}$ and $2^{\text {nd }}$ year was minimum $\left(9.2\right.$ and $\left.9.9^{\circ} \mathrm{C}\right)$ under PSM as compared to $16.5^{\circ} \mathrm{C}$ in control plots throughout the investigation period. The soil temperature under PSM was higher during extreme winters whereas, it was comparatively lower during pre and post-winter season as compared to other treatments. The variations in intra-day average soil temperature during the months of October-November and again in March-April was higher than in December-February; the period of extreme winters. Significant reduction in physiological fruit drop was recorded under all the treatments with minimum fruit drop under PSM followed by BPM, while it was maximum in control trees. Likewise, fruit weight and fruit yield was also recorded highest under PSM followed by BPM treatments. The microbes in the rhizopshere of mulched trees with PSM followed by BPM exhibited highest and sustained activity from from Otober to April month under North-West Indian conditions.
\end{abstract}

Key words: Soil temperature, mulching, yield, ber.

Under North-West Indian conditions, profuse vegetative growth along with flowering and fruit setting initiates after the rainy season in Indian ber (Zizypus mauritiana Lamk.) trees. The fruit development of ber coincides with cold weather which contributes to physiological fruit drop resulting in lesser crop yield. Furthermore, most of the ber plantation in this region exists in areas of sandy soils and water scarcity resulting water stress during peak fruit development phase causing increment in physiological fruit drop. Moreover, the luxuriant vegetative growth filled with thorny shoots emerges from October onwards makes it difficult to manage the simultaneously growing weeds on the orchard floor. Hence; the conservation of soil moisture, sustained soil temperature and suppression of weeds during fruit growth and development is of utmost importance for higher yield and quality fruits. Modification of soil microclimate using mulches is a highly successful adaptive approach (Panging et al, 2019). Covering of soil surface or mulching the base of the tree with certain materials maintain or improve the physical properties of soil, sustain the soil microclimate conducive for plant growth and development of fruits under extreme weather conditions. Mulches conserve the soil moisture, regulate soil temperature, improve the soil aeration, suppress the weed flora, increase in organic matter content and improve the soil micro-organisms activity (Tyagi et al., 2018). Mulches have multiple favorable influences under the conditions of extreme soil temperature fluctuation, hot and dry weather and under deficit soil moisture conditions (Shirgure et al., 2003). The organic mulches are quite effective in decreasing nitrates leaching, improving physical properties of soil, preventing erosion, addition of organic matter, regulation of temperature, improvement in water retention, nitrogen balance as well as microbial activities in soil (Muhammad et al., 2009). Being impermeable to water, the plastic mulches thwart the evapotranspiration loss of water and also buffers the soil temperature which facilitates the continuous functioning of roots even under cold conditions. Mulches protect the plants from extreme temperatures and maintain the optimum temperature conditions (Montague and Kjelgren, 2004). Mulching decreases the daily maximum soil temperature resulting in earliness of tuber emergence and plant growth with subsequent yield improvement in potato (Jaiswal, 1995). 
Skroch et al (1992) also reported that maximum soil temperature was reduced by 2.3 to $3.3{ }^{\circ} \mathrm{C}$ and minimum temperature was increased by 1.1 to $2.2^{\circ} \mathrm{C}$ under mulching. Regulated soil temperature under water hyacinth mulch results in increment in leaf area index, biomass production and ultimate tuber yield of potato as compared to other mulchs (Panging et al., 2019). The activity of soil microbes is variable under different mulches and existing weather conditions and some researchers reported improvement (Chen et al., 2017), while others reported decreased microbial activity (Moreno and Moreno, 2008) with mulches. Therefore, this study aimed to compare the effects of different types of mulches and other orchard floor management treatments on soil temperature, soil microbial activities and physico-chemical tratits of Indian ber fruits.

\section{MATERIALS AND METHODS}

The experiment was laid out at the Fruit Research farm, Department of Fruit Science, Punjab Agricultural University, Ludhiana (India) during 2018-19 and 2019-20 on 15-year-old berplants. Different types of mulches viz. paddy straw mulch (PSM), white polythene mulch (WPM) and black polythene mulch (BPM) were applied under the canopie of Indian ber (Zizypus mauritiana Lamk.) trees. The chemical weed management (CWM) with application of post emergence herbicide Paraquat @ 1.2 liters/acre, intercultivation (IC) with rotavator and the weedy check (control) were also kept for cpmarative analysis. The paddy straw was applied by spreading $10 \mathrm{~cm}$ thick mulch layer under the tree canopy@ 12.5 ton per hectare (70-80 \% of total orchard floor) during the second fortnight of October. The black (BPM) as well as white polythene mulch (WPM) of $38 \mu$ thickness was also applied in similar fashion. These treatments were given after application of second split dose of urea ( $500 \mathrm{~g} /$ tree $)$. Each type of mulch was applied to a group of 3 trees taken as unit and was replicated thrice to evaluate the relative efficacy of the mulching material and other floor management treatments. The control trees were kept as such without mulching and the application of any floor management practices.

The soil temperature was recorded from third week of October to second week of April twice in a week at 9.00, $12.00,14.30$ and 17.00 hours using soil thermometers at 10 $\mathrm{cm}$ soil depth. Terminal shoots $(50 \mathrm{~cm})$ in each direction of the tree canopy of experimental plants were randomly selected and tagged for the calculation of fruit set and fruit retention. Fruit set (FS) was recorded by counting the fruits on tagged shoots of the experimental plants. Average fruit weight was recorded by weighing 40 randomly selected fruits per plant and yield was calculated by weighing the fruit load on each tree. The biochemical characteristics of ber fruits in terms of total soluble solids (TSS) and acid content were recorded during last week of March for both years as per the standard procedure (AOAC, 2000). Serial dilution spread plate technique was used for the counting of bacteria, fungi and actinomycetes colonies under all muched and non-mulched trees. The media for the enumeration of microbial count was prepared followed by sterilization for 20 minutes in an autoclave at a temperature of $121^{\circ} \mathrm{C}$ with pressure of 15 psi. After incubation, the counting of the number of colonies appearing on dilution plates was done to calculate the number of cells per gram of soil sample.

\section{RESULTS AND DISCUSSION}

The soil temperature recorded from the third week of October to the second week of April exhibited significant variations under different floor management treatments during both years (Fig.1). Soil temperature exhibited declining trend from October to December, while it remained almost static up to the month of February. Subsequently, the soil temperature showed rising trend with steady increment from February to April. However, under paddy straw mulching, the soil temperature registered gradual changes and remained within the favorable range during the entire period of investigations, as it sustained the soil temperature higher during extreme winter months and vice versa as compared to all other treatments. During the month of October, the soil temperature was 4.62 and $4.95^{\circ} \mathrm{C}$ lower during $1^{\text {st }}$ and $2^{\text {nd }}$ year, respectively under PSM as compared to control trees. Whereas, the respective temperature remained 2.97 and $2.21^{\circ} \mathrm{C}$ lower during next month in both years as comaperd to control (Fig 2). Subsequently, during months of December, January and February, an increment in soil temperature by $0.6,1.9$ and $0.7^{\circ} \mathrm{C}$ during $1^{\text {st }}$ year and $1.63,2.34$ and $1.7^{\circ} \mathrm{C}$ during $2^{\text {nd }}$ year was recorded under PSM, respectively. The PSM again maintained the lower soil temperature during March $\left(0.9\right.$ and $\left.0.7^{\circ} \mathrm{C}\right)$ and April (3.81 and $3.35^{\circ} \mathrm{C}$ ) as comaperd to control plots, respectively. The average soil temperature variations from October to January months was minimum under PSM treatment with difference of only 9.2 and $9.9^{\circ} \mathrm{C}$ during $1^{\text {st }}$ and $2^{\text {nd }}$ year, respectively as compared to $16.5^{\circ} \mathrm{C}$ in control plots during both the years (Fig.3). The similar trend of temperature variations was also noticed under other treatments as well. Mulching regulate the soil microclimate, primarily soil moisture and temperature 

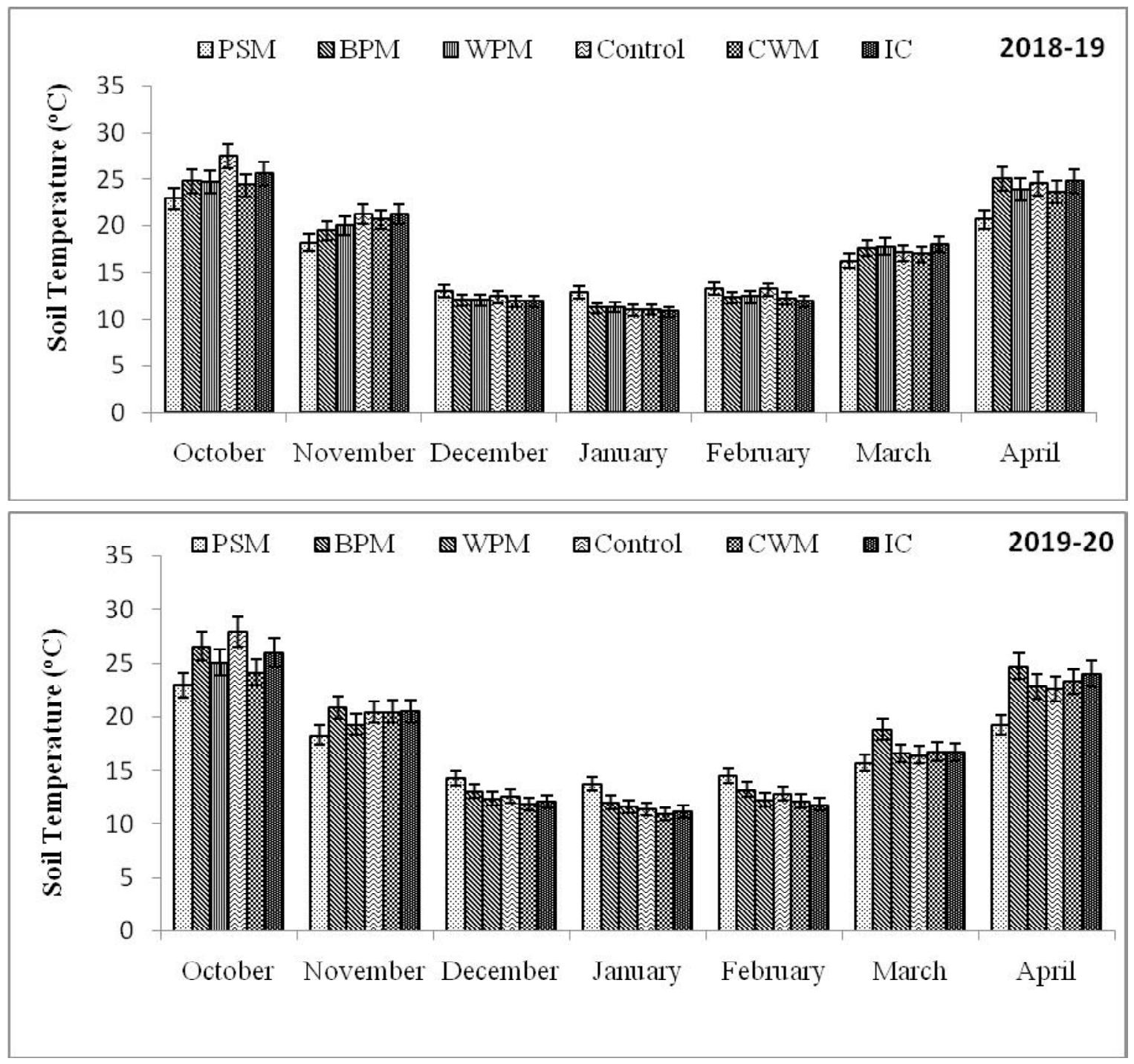

Fig. 1: Average soil temperature under different mulching treatments inber orchard for two consecutive years (2018-19 and 2019-20).

(Baten et al., 1995) and manage temperature fluctuations in addition to improvement in soil physical, chemical as well as biological characteristics. Lotze and Kotze (2014) reported increment of $1^{\circ} \mathrm{C}$ for minimum temperature and up to $5^{\circ} \mathrm{C}$ for maximum temperature during summer in the top $50 \mathrm{~mm}$ soil. Likewise, plastic mulches improved the hydrothermal conditions of soil (Hai et al., 2015; Wang et al., 2016). Lesser soil temperature during entire season under combination of mulch and herbicide treatment then sole treatments of clean cultivation, herbicidal application and control was also reported in plum (Kumar, 1984) and apricot (Sharma, 1985) orchards. Fourie and Freitag (2010) also reported reduction in soil temperatures during summers and curtailing diurnal variation in soil temperature with the use of mulches in orchards.

Variations in intra-day soil temperature was also observed in all treatments (Fig. 4). All the treatments exhibited rise in average monthly soil temperature from 9.00 am to $17.00 \mathrm{pm}$ during the months of October and November. However, during next two months the soil temperature exhibited rising trend upto $14.30 \mathrm{pm}$ and afterward up to $17.00 \mathrm{pm}$, it was declined among all treatments. Subsequently, in the month of February, the evening (5.00 $\mathrm{pm})$ soil temperature remained almost same as that of noon $(2.30 \mathrm{pm})$ temperature. Afterward, in March and April the intra-day soil temperature, increased throughout the day from 9.00 am to $5.00 \mathrm{pm}$ in all the treatments. The intra-day average soil temperature variations among all treatments during the months of October to January were higher than February and again increased March onward. Mulching reduces the solar energy reaching the soil surface resulting reduction in day temperature flux and insulating against loss 


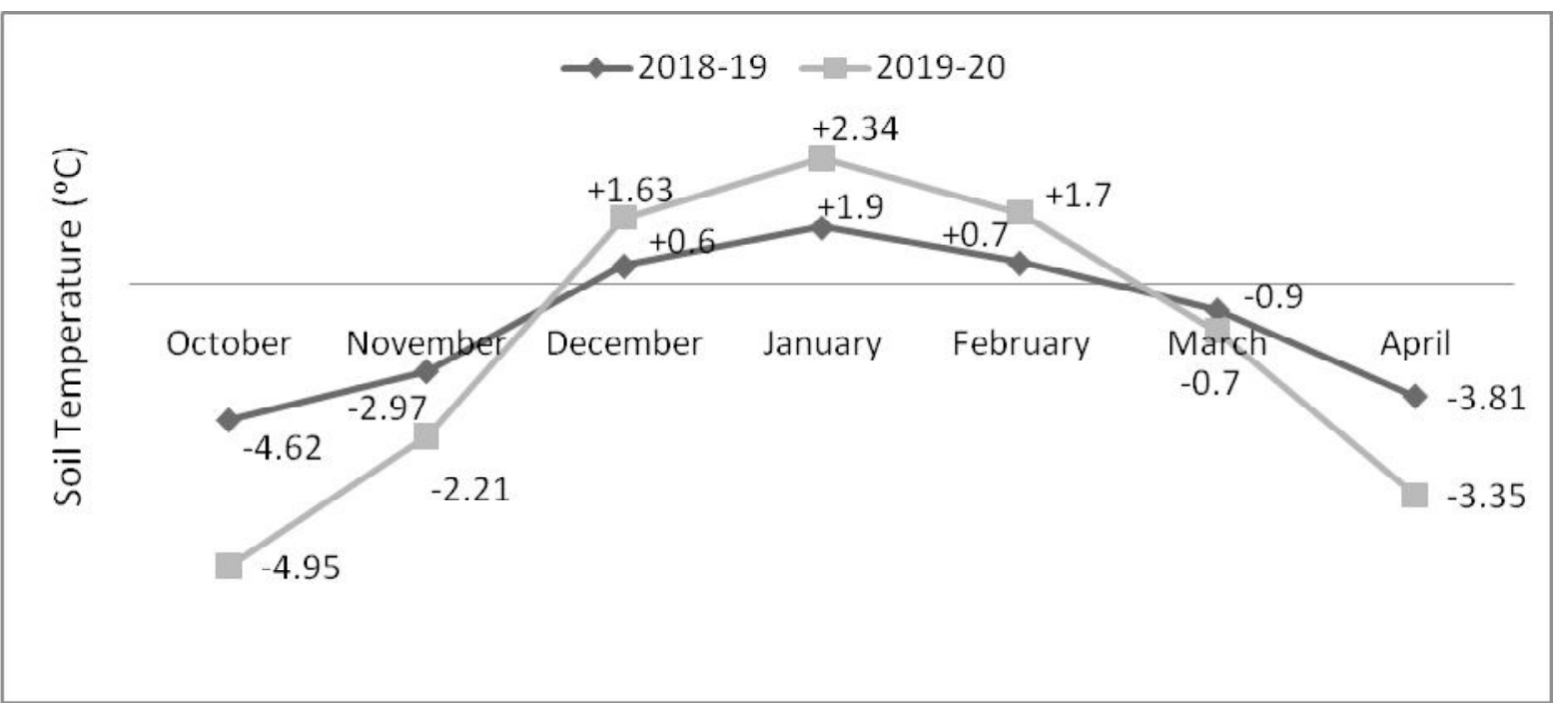

Fig. 2: The soil temperature variations of PSM treatments than control tree ( October-April) during $1^{\text {st }}(2018$ $19)$ and $2^{\text {nd }}$ year $(2019-20)$

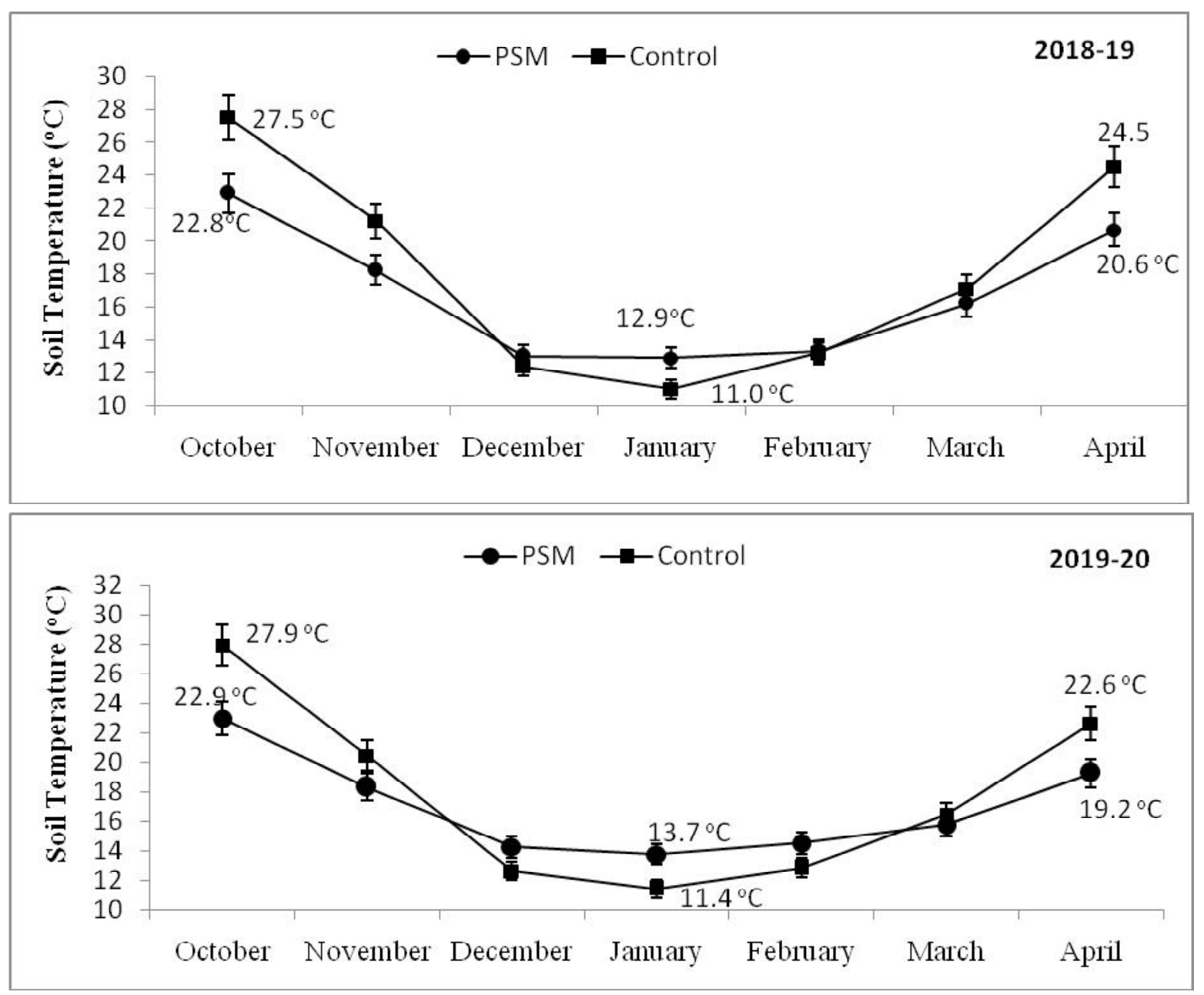

Fig. 3: Comparison of soil temperature variation $\left({ }^{\circ} \mathrm{C}\right)$ under paddy straw mulch and control trees in ber orchards for two consecutive years (2018-19 and 2019-20). 


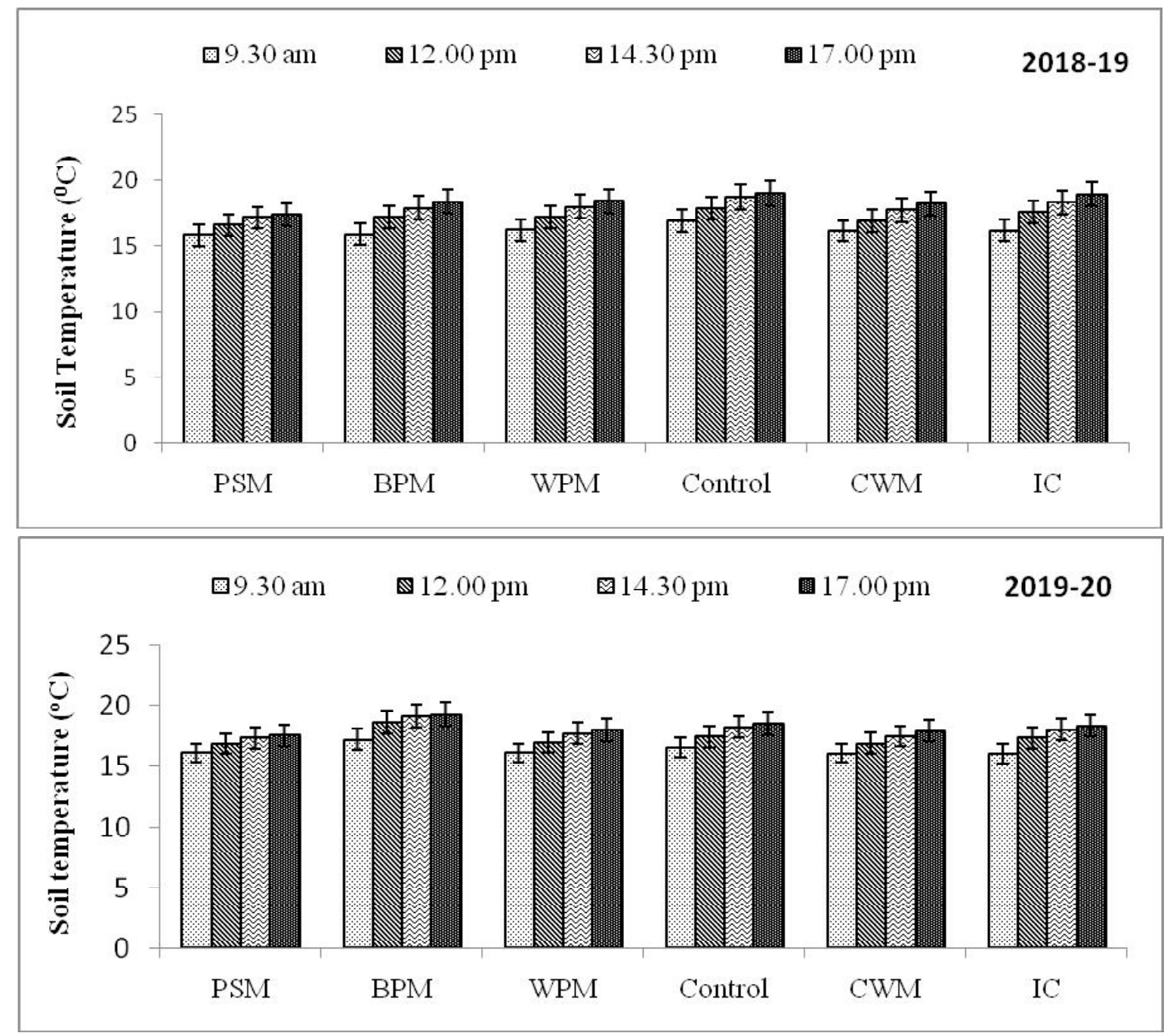

Fig. 4: Intra-day average temperature variation $\left({ }^{\circ} \mathrm{C}\right)$ under different floor management practicesin ber orchards for two consecutive years (2018-19 and 2019-20).

Table 1: Effect of different mulching material and orchard floor management treatments on fruit drop, yield and quality of berfruits (2018-19 and 2019-20)

\begin{tabular}{llllllllllll}
\hline Treatments & \multicolumn{2}{c}{ Fruit drop (\%) } & \multicolumn{2}{c}{ Fruitweight (g) } & Yield/tree (kg) & \multicolumn{2}{c}{ TSS (\%) } & \multicolumn{2}{c}{ Acidity (\%) } \\
& $2018-19$ & $2019-20$ & $2018-19$ & $2019-20$ & $2018-19$ & $2019-20$ & $2018-19$ & $2019-20$ & $2018-19$ & $2019-20$ \\
\hline Paddy straw mulch(PSM) & 22.82 & 20.45 & 25.2 & 25.2 & 108.6 & 123.8 & 14.2 & 14.3 & 0.23 & 0.26 \\
Black polythenemulch(BPM) & 25.28 & 23.46 & 25.3 & 25 & 106.5 & 120.3 & 14.3 & 14.4 & 0.25 & 0.27 \\
White polythenemulch(WPM) & 25.78 & 28.81 & 24.8 & 24.7 & 102.6 & 106.8 & 14.1 & 14.4 & 0.24 & 0.25 \\
Control & 32.51 & 29.94 & 24.2 & 24.4 & 91.0 & 104.9 & 14.0 & 14.2 & 0.24 & 0.25 \\
ChemicalWeedManagement(CWM) & 28.16 & 26.18 & 24.8 & 24.5 & 100.4 & 110.5 & 14.0 & 14.3 & 0.24 & 0.26 \\
Inter-cultivation(IC) & 28.89 & 26.24 & 24.9 & 24.4 & 99.6 & 113.1 & 14.2 & 14.2 & 0.26 & 0.25 \\
CDat5\% & 2.05 & 1.68 & NS & NS & 5.85 & 7.10 & NS & NS & NS & NS \\
\hline
\end{tabular}

of radiant heat during night (Thompson and Grime, 1983).

Although, all the floor management treatments reduced the physiological fruit drop, improve fruit weight and yield but, paddy straw mulching (PSM) was significantly effective followed by black polythene mulch (Table.1). Significant reduction in physiological fruit drop was recorded under all the treatments with minimum fruit drop (22.82 and 


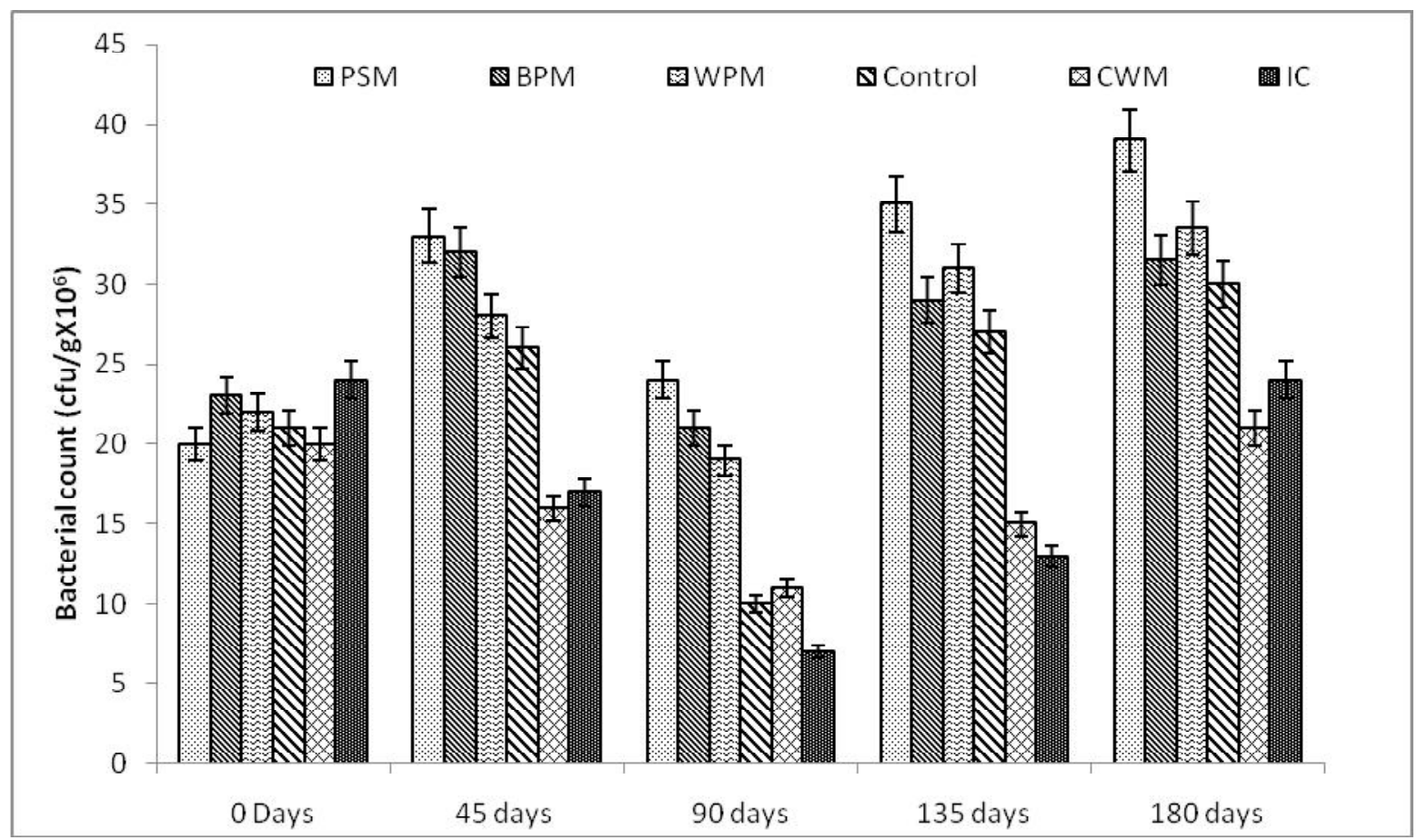

Fig. 5: Effect of different mulching treatments on Bacterial count $\left(\mathrm{cfu} / \mathrm{g} \times 10^{6}\right)$ of soilinber orchards for two consecutive years (2018-19 and 2019-20).

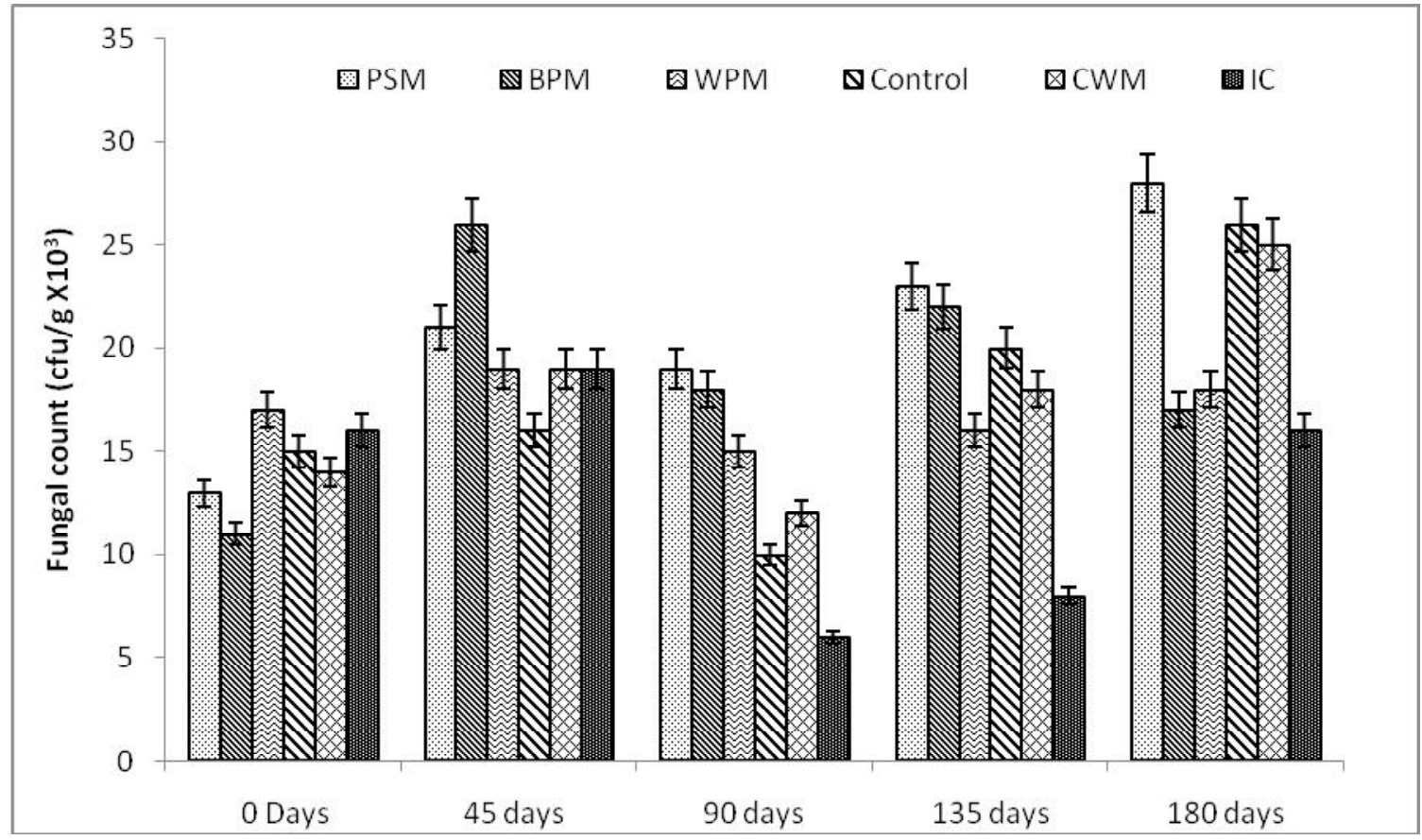

Fig. 6: Effect of different mulching treatments on Fungal count $\left(\mathrm{cfu} / \mathrm{g} \mathrm{x} 10^{3}\right)$ of soil in ber orchards for two consecutive years (2018-19 and 2019-20).

$20.45 \%$ and) under PSM followed by 20.45 and $23.46 \%$ under BPM, as compared to 32.51 and $29.94 \%$ in control trees during $1^{\text {st }}$ and $2^{\text {nd }}$ year, respectively. Likewise, during respective years, the average fruit weight was also recorded maximum in PSM (25.2 g) and BPM (25.3 and 25.0 g), while it was minimum ( 24.2 and $24.4 \mathrm{~g})$ in control trees. The fruit yield obtained from the trees mulched with PSM (108.6 and $123.8 \mathrm{~kg}$ ) followed by 106.5 and $120.3 \mathrm{~kg}$ under BPM as compared to 91.0 and $104.9 \mathrm{~kg}$ per tree in control treatment, respectively. However, the quality of ber in terms of total 
soluble solids and titratable acidity was statistically at par under all treatments. Reduction in physiological fruit drop and increment in fruit weight might be attributed to regulation of soil temperature and retention of soil moisture under mulching, that ultimately contributed to higher fruit yield. Paddy straw mulching helps to sustain the soil temperature during extreme winters and summers in addition to retention of moisture around root zone of the trees. Such conditions reduce the physiological fruit drop triggered by imbalance of endogenous growth hormones caused by abiotic stress such as deficit soil moisture and low soil as well as atmospheric temperature. Mulches have marked influence on the plant growth and development as these amend the physio-chemical properties of soil and also alter the soil hydrothermal regime (Hedua and Kumar, 2002). Reduction in soil temperature during summer and increment during winters prevents the plants from the adverse effects of extremes of soil temperatures under mulching (Kumar and Lal, 2012). Similarly, readily available soil water and optimum soil temperature conditions during fruit development phase results improvement in fruit size under mulching particularly PSM and BPM. Higher fruit size and better fruit retention under mulching improved the fruit yield. Moreover, the nutrient supply and sustained microbial activity under mulches further helped in increment in fruit size and ultimate yield. Mulching enrich the soils with addition of essential nutrients and ultimately aid the plant growth and crop (Kar 2003; Saikia et al. 2014).

The activity of soil microbes is variable under different mulches and existing weather conditions. The microbial activity in terms of bacterial (Fig. 5) and fungal (Fig. 6) count under different mulching and floor management treatments varied significantly during October to April months. During first 45 days of treatment applications, the bacterial count increased under all types of mulching materials while, it was declined under non-mulched plots. However, up to 90 days it was decline drastically under all treatments, whereas progressive increase in bacterial count was noted upto 180 days under all treatments including control. The highest bacterial activity was recorded under PSM followed by BPM. Likewise fungal count also exhibited the same pattern of activity under mulching and non-mulching treatments. PSM exhibited highest fungal count, while it was least under treatment of Interc-cultivation (IC). Under low ambient temperature, mulches increase the soil temperature suitable for microbial activity and under high ambient temperature the mulches further rise the temperatures limiting the soil microbial activity (Moreno and Moreno, 2008). Garg et al
(2003) also reported highest fungal and bacterial counts in banana leaf mulch treatment in the soil rhizosphere of meadow guava (Psidium guajava L.) orchards, followed by black polyethylene mulch. Esther et al (2012) reported maximum bacterial count in acid lime orchard mulched with paddy straw and minimum in control. While, the highest microbial population count for fungi was recorded in rice husk mulch followed by paddy straw mulch. They further reported no microbial growth of fungi in control plants.

\section{CONCUSION}

From the investigations, it may be concluded that paddy straw mulching in ber orchards helped to maintain the soil temperature favourable for the different phenological events beginning from fruit setting to ultimate fruit maturity. Sustained soil temperature, conserved soil moisture and persistent microbial activity under mulching particularly under this organic mulch lead to reduction in the physiological fruit drop, increment in fruit weigh and ultimate yield of trees.

\section{RFERENCES}

A.O.A.C. (2000). Official and Tentative Methods of Analysis, Association of Official Agric Chemists, $15^{\text {th }} \mathrm{Ed}$. Washington, DC, USA.

Baten, M.A., Nahar, B.S., Sarker, S.C and Khannn, M.A.H (1995). Effect of different mulches on the growth and yield of late planted garlic (Allium Sativum L.). Pak. J. Sci. Ind. Res., 38: 138-141.

Chen, H., Liu, J., Zhang, A., Chen, J., Cheng, G. and Sun, B. (2017). Effects of straw and plastic film mulching on greenhouse gas emissions in Loess Plateau, China: a field study of 2 consecutive wheat-maize rotation cycles. Sci. Total Environ., 579 : 814-824.

Esther, L., Hazarika, B.N. and Raja, P. (2018). Effect of paddy straw and rice husk mulching on soil microbial population in acid lime (Citrus aurantifolia Swingle). Adv. Biotech. Micro., 12(1):1-2.

Garg, N., Singh, G., Yadav, P., Goel, N. and Soni, M.K. (2007). Effect of mulching on soil microbial population in guava (Psidium guajava L.) orchard soil. Indian J. Agric. Sci., 77 (4): 241-243.

Fourie, J.C. and Freitag, K. (2010). Soil management in the Breede river valleywine grape region, South Africa. $S$. Afr. J. Enol. Vitic., 31: 165-168. 
Hai, L., Li, X.G., Liu, X.E., Jiang, X.J., Guo, R. Y., Jing, G.B., Rengel, Z. and Li, F.M. (2015). Plastic mulch increase soil nitrogen mineralization in a semiarid environment. Agron. J., 107: 921-930.

Hedua, N.K. and Kumar, M. (2002). Effect of different mulches on yield, plant height, nitrogen uptake, weed growth, soil moisture and economics of tomato. Prog. Hort., 34(2): 208-210.

Jaiswal, V.P.(1995). Response of potato (Solanum tuberosum) cultivars to date of planting and mulching under warm temperature condition. Indian J. Agron., 40: 660-664.

Kar, G. (2003). Tuber yield of potato as influenced by planting dates and mulches. J. Agrometeorol., 5(1):60-67.

Kumar, J. (1984). Effect of various systems of orchard soil management at different levels of nitrogen in Santa Rosa plum. Ph.D. Thesis, Himachal Pradesh Krishi Vishva Vidyalaya, Palampur(H.P.).

Kumar, S.D. and Lal, B.R. (2012). Effect of mulching on crop production under rainfed condition. Int. J. Res.Chem. Env., 2(2): 8-20.

Lotze, E. and Kotze, W.P. (2014). The effect of organic and inorganic mulches on soil environment, root development and nutrient uptake of mature apple trees. Acta Hortic., 1018: 391-400.

Montague, T. and Kjelgren, R. (2004). Energy balance of six common landscape surfaces and the influence of surface properties on gas exchange of four containerized tree species. Sci. Hortic., 100: 229-249.

Moreno, M.M. and Moreno, A. (2008). Effect of different biodegradable and polyethylene mulches on soil properties and production in a tomato crop. Sci. Hortic., 116: 256-263.

Muhammad, A.P., Muhammad, I., Khuram, S. and Anwar-ULHassan. (2009). Effect of mulch on soil physical properties and NPK concentration in maize (Zea mays) shoots under two tillage system. Int. J. Agric. Biol., 11: 120-124.
Panging, M., Neog, P., Deka, R. and Medhi, K. (2019)Assessment of performance of potato crop under modified microclimates in rice based cropping system of Upper Brahmaputra valley zone of Assam. J. Agrometeorol., 21(3): 249-253.

Saikia, U.S., Kumar, A., Das, S., Pradhan, R., Goswami, B.,Wungleng, V.C., Rajkhowa, D.J. and Ngachan, S. V. (2014). Effect of mulching on microclimate growth and yield ofmustard under mid-hill condition of Meghalaya. J. Agrometeorol., 16(1):144-145.

Sharma, R.K. (1985). Studies on the effect of mulch material and weedicides on the growth, cropping and quality of New Castle apricot. M.Sc. Thesis, Himachal Pradesh Krishi Vishwa Vidyalaya, Palampur(H.P.).

Shirgure, P.S., Sonkar, R.K., Shyam, S. and Panigrah, P. (2003). Effect of different mulches on soil moisture conservation, weed reduction, growth and yield of drip irrigated Nagpur mandarin (Citrus reticulata). Indian J. Agric. Sci., 73: 148-152.

Skroch, W.A., Powell, M.A., Bilderback, T.E. and Henry, P.H. (1992). Mulches: Durability, aesthetic value, weed control and temperature. J. Environ. Hortic., 10: 43-45.

Thompson, K. and Grime, J.P. (1983). A comparative study of germination responses to diurnally-fluctuating temperatures. J. Appl. Ecol., 20: 141-156.

Tyagi, S., Singh, A., Sahay, S. and Kumar, N. (2018). Mulching for Commercial Fruit Production. In Dimensions of Agricultural Science. Ed. PK Ohja, Kaliayni Publisher, 292-307.

Wang, Y.P., Li, X. G., Fu, T., Wang, L., Turner, N.C., Siddique, K.H.M. and Li, F.M. (2016). Multi-site assessment of the effects of plastic-film mulch on the soil organic carbon balance in semiaridareas ofChina.Agr. Forest. Meteorol., 228-229: 42-51 